\title{
The efficacy and safety of add-on $0.1 \%$ brimonidine tartrate preserved with sodium chlorite in on-treatment Japanese normal-tension glaucoma patients [Corrigendum]
}

\author{
Tsumura T, Yoshikawa K, Kimura T, et al. Clin Ophthalmol. \\ 2014;8:1681-1687.
}

The authors would like to make corrections to Table 3, on page 1684 , as some of the data were incorrect. The revised version of Table 3 is shown below.

Table 3 Time course of conjunctival hyperemia and superficial punctate keratitis (SPK) scores ${ }^{\mathrm{a}}$

\begin{tabular}{lllll}
\hline & Baseline & $\mathbf{4}$ weeks & $\mathbf{8}$ weeks & I2 weeks \\
\hline Conjunctival hyperemia scores & $0.6 \pm 0.7$ & $0.5 \pm 0.7$ & $0.5 \pm 0.7$ & $0.5 \pm 0.7$ \\
$P$-value & & 0.4545 & 0.0768 & 0.3750 \\
SPK scores & $0.2 \pm 0.3$ & $0.1 \pm 0.2$ & $0.2 \pm 0.3$ & $0.2 \pm 0.3$ \\
$P$-value & & 0.5309 & 0.438 I & 0.6245 \\
\hline
\end{tabular}

Notes: aScores are presented as the mean \pm standard deviation: analyzed by Wilcoxon signed rank test.

Clinical Ophthalmology is an international, peer-reviewed journal covering all subspecialties within ophthalmology. Key topics include: Optometry; Visual science; Pharmacology and drug therapy in eye diseases; Basic Sciences; Primary and Secondary eye care; Patien Safety and Quality of Care Improvements. This journal is indexed on
PubMed Central and CAS, and is the official journal of The Society of Clinical Ophthalmology (SCO). The manuscript management system is completely online and includes a very quick and fair peer-review system, which is all easy to use. Visit http://www.dovepress.com/ testimonials.php to read real quotes from published authors. 